Contract No. and Disclaimer:

This manuscript has been authored by Savannah River Nuclear Solutions, LLC under Contract No. DE-AC09-08SR22470 with the U.S. Department of Energy. The United States Government retains and the publisher, by accepting this article for publication, acknowledges that the United States Government retains a non-exclusive, paid-up, irrevocable, worldwide license to publish or reproduce the published form of this work, or allow others to do so, for United States Government purposes. 


\title{
Beryllium Measurement in Commercially Available Wet Wipes
}

*Linda D. Youmans-McDonald linda.youmans-mcdonald@srs.gov, *Mike Brisson mike.brisson@srs.gov, *Maureen Bernard Maureen.bernard@srs.gov, Savannah River Nuclear Solutions LLC, Aiken, SC 29808, USA

Anoop Agrawal aaagrawal@qwestoffice.net, John P. Cronin jcronin@qwestoffice.net, Lori Adams 1lcadams@qwestoffice.net Berylliant Inc., 4541 East Fort Lowell Road Tucson, AZ 85712, USA

Disclaimer: *Mention of commercial products in this article does not imply endorsement by the author, SRNS, SRS, or the U.S. Department of Energy (DOE).

\begin{abstract}
Analysis for beryllium by fluorescence is now an established method which is used in many government-run laboratories and commercial facilities. This study investigates the use of this technique using commercially available wet wipes. The fluorescence method is widely documented [1-4] and has been approved as a standard test method by ASTM International and the National Institute for Occupational Safety and Health (NIOSH). The procedure involves dissolution of samples in aqueous ammonium bifluoride solution and then adding a small aliquot to a basic hydroxybenzoquinoline sulfonate fluorescent dye (Berylliant ${ }^{\mathrm{TM}}$ Inc. Detection Solution Part \# CH-2), and measuring the fluorescence. This method is specific to beryllium. This work explores the use of three different commercial wipes spiked with beryllium, as beryllium acetate or as beryllium oxide and subsequent analysis by optical fluorescence. The effect of possible interfering metals such as $\mathrm{Fe}$, Ti and $\mathrm{Pu}$ in the wipe medium is also examined.
\end{abstract}




\section{Introduction}

Sampling for beryllium is expected to increase both in the Department of Energy and commercial industry, as the health risk associated with beryllium exposure is more widely understood. In order to deal with this expected increase in samples, more efficient and less labor intensive methods were investigated . Current beryllium analysis by hydrofluoric acid (HF) or sulfuric acid $\left(\mathrm{H}_{2} \mathrm{SO}_{4}\right)$ digestion [5] and the removal of spectral interferences by ion exchange before measurement by sequential Inductively Coupled Plasma-Atomic Emission Spectrometer (ICP-AES)is very labor intensive [6], resulting in long turnaround times. One method which meets the requirements of low cost and fast turnaround is optical fluorescence [7], which has been recently established as a standard test procedure for determining beryllium in particles collected on wipe samples, air filters and soil samples. These methods are available as ASTM method D7202 [8] and D7458 [9], and NIOSH 7404 and 9102 [10]. Alternative methods used to analyze beryllium are graphite furnace atomic absorption spectrometry (GFAAS), inductively coupled plasma atomic emission spectrometry (ICP-AES) and inductively couple plasma mass spectrometry (ICP-MS) [11-12]. Compared to the other methods, the fluorescence method is not sensitive to interference by other metals present $[6,13]$ and has beryllium detection limits comparable to the most sensitive method using ICP-MS.

Dufay and Archuleta [14] reported work on the collection efficiency of some of the wet and dry commercial wipes for analysis of beryllium. However, limited work has been reported on the use of commercial individually packaged wet wipes as host media for beryllium and their analysis by optical fluorescence; further there is no established consensus standard specification for wet wipes that can be used for beryllium surface sampling. Commercially available wipes are not required to adhere to a standard that 
ensures their suitability for beryllium measurement. Hence there is no requirement for any commercial provider that the wipes used for beryllium sampling will not vary in material, preservative, or even background beryllium concentration, and this is a concern for any analytical method used for beryllium measurement. Issues related to commercial wet wipes are variability in their composition, size, amount of wetting agent and addition of additives such as surfactants and anti microbial agents and variations between lots. Specifically, when optical fluorescence is used as the analytical method, there is a possibility that, in addition to any background from beryllium (if present), other constituents from the wipe may react or dissolve to give products which have an emission and excitation spectrum overlapping with the fluorescent spectrum of the dye associated with beryllium; this will manifest as a positive bias resulting in an increased beryllium concentration.

In this study we investigated three commercial wipes, Palintest ${ }^{\mathrm{TM}}$, Ghost Wipe ${ }^{\mathrm{TM}}$ and Mixed Cellulose Ester (MCE) filters. The effect of these wipes on beryllium analysis was investigated by combining the commercial wipe with a beryllium oxide spiked MCE filter or by directly spiking the wipe with beryllium acetate and analyzing by optical fluorescence. Also added to the wipe during the ABF dissolution process where known quantities of the metals such as $\mathrm{Fe}, \mathrm{Ti}$ and $\mathrm{Pu}$ to investigate whether these interactions will cause a systematic error. 


\section{Methods}

Three types of wipe media were used in this study and their details are listed in Table 1. The Ghost Wipes ${ }^{\mathrm{TM}}$ and Palintest ${ }^{\mathrm{TM}}$ wipes were spiked with beryllium acetate while the MCE filters with high-fired $\mathrm{BeO}$ (Standard reference Material (SRM) 1877 from the National Institute of Standards and Technology, Gaithersburg, MD). To test the effect of interfering metals on the analysis, Fe (chloride), Ti (dioxide), and Pu were added to the mixture in concentrations respectively of $10 \mathrm{mg}, 2 \mathrm{mg}$ and $5 \times 10^{6}$ disintegrations per minute (dpm). Two different lot numbers of the Ghostwipes were tested to check for any variations between batches.

Table 1: Commercial wet wipes and filters used for analysis of beryllium using optical fluorescence

\begin{tabular}{|l|l|l|}
\hline Material & Properties & Vendor \\
\hline $\begin{array}{l}\text { Palintest } \\
\text { wipe }\end{array}$ & $\begin{array}{l}\text { Meets ASTM E 1792 } \\
\text { Size } 17.9 \times 12.7 \mathrm{~cm}\end{array}$ & $\begin{array}{l}\text { Palintest USA, } \\
\text { Erlanger, KY }\end{array}$ \\
\hline $\begin{array}{l}\text { Ghost } \\
\text { Wipe }^{\text {TM }}\end{array}$ & $\begin{array}{l}\text { Meets ASTM E 1792 } \\
\text { Size 15 x 15 cm (or 15 X } \\
14 \mathrm{~cm})\end{array}$ & $\begin{array}{l}\text { Environmental Express, Mt. } \\
\text { Pleasant, SC }\end{array}$ \\
\hline MCE filter & $\begin{array}{l}\text { Blank and spiked with } \\
\text { beryllium acetate or oxide }\end{array}$ & $\begin{array}{l}\text { High-Purity Standards } \\
\text { Charleston, SC }\end{array}$ \\
\hline
\end{tabular}

For determination of beryllium by fluorescence, the wipe samples were subjected to a dissolution process by placing them in $20 \mathrm{ml}$ of $1 \%$ ammonium bifluoride (ABF) and heating to $90^{\circ} \mathrm{C}$ for 60 minutes. Because of the large size of the wipes, $20 \mathrm{ml}$ of $\mathrm{ABF}$ was chosen to get complete immersion of the wipe so that beryllium could be effectively extracted in the dissolution solution. The liquid, after extraction, was then analyzed using $5 \mathrm{X}$ dilution [2] where $0.4 \mathrm{ml}$ of the dissolution solution was added to $1.6 \mathrm{ml}$ of a detection solution containing 1.1mM HBQS (hydroxybenzoquinoline sulfonate), $1 \mathrm{mM}$ ethylenediamine tetraacetic acid and $100 \mathrm{mM}$ L-Lysine monochloride with the solution pH adjusted to 12.85 (Berylliant, Inc., Tucson, AZ). The fluorescence measurements for 
beryllium quantification were performed using a Turner BioSystems Modulus

fluorometer (Sunnyvale, CA) with a bandpass filter for excitation and emission. The filter transmission characteristics were $365 \pm 10 \mathrm{~nm}$ and $480 \pm 5 \mathrm{~nm}$ for excitation and emission, respectively. The fluorometer was calibrated using solutions of $0.1 \mathrm{ppb}$ to $16 \mathrm{ppb}$ of beryllium.

\section{Results and Discussion}

The unique aspect of the fluorescence method to detect beryllium is the use of the fluorescence dye (HBQS) which specifically binds to beryllium. The phenolic group binds strongly to beryllium where the six member ring has the ideal distance between O$\mathrm{O}$ or $\mathrm{N}-\mathrm{O}$ for chelating $\mathrm{Be}[13]$. A tightly bound hydrogen bonded proton leads to a weak triplet emission at $580 \mathrm{~nm}$ for the dye solution. When the proton is displaced by a metal such as beryllium, peak fluorescence emission is observed between 475 to $480 \mathrm{~nm}$ [12]. Because of the large size of the commercial wipes, higher volumes of $1 \mathrm{wt} \% \mathrm{ABF}$ were required (20 $\mathrm{ml}$ as opposed to $5 \mathrm{ml}$ ) to completely submerge the wipe during the dissolution process. This results in a higher dilution and required reevaluation of the detection limits of the method. To test the viability of the commercial wipes for use with the fluorescence method, their background fluorescence signal was first established. This was done for the Palintest ${ }^{\mathrm{TM}}$ and Ghost Wipes ${ }^{\mathrm{TM}}$ spiked with beryllium acetate, as well as MCE filters spiked with beryllium oxide. These data are shown in Table 2. The blank Palintest ${ }^{\mathrm{TM}}$ wipe has a significant background fluorescence signal higher than the DOE limit of $0.02 \mu \mathrm{g}$, whereas the Ghost Wipe ${ }^{\mathrm{TM}}$ and MCE filter have background fluorescence signals below the method detection limits. The additive factor of this background signal is seen when the Palintest ${ }^{\mathrm{TM}}$ wipe is spiked with $0.04 \mu \mathrm{g}$ of beryllium, as beryllium acetate. The recoveries for Palintest ${ }^{\mathrm{TM}}$ are all significantly above $100 \%$. The 
Ghost Wipes ${ }^{\mathrm{TM}}$ and MCE filters, on the other hand, have recovery values on average in the range $93-103 \%$. Because of the high background fluorescence of the Palintest ${ }^{\mathrm{TM}}$ wipes, they were deemed unsuitable for use with optical fluorescence. Previous lots of Palintest wipes did not demonstrate this problem [3].

Table 2: Background and Be spiked fluorescence data for commercial wipes

\begin{tabular}{|c|c|c|c|}
\hline & $\begin{array}{c}\text { Palintest }^{\mathrm{TM}} \text { wipe } \\
\text { (\% recovery) }\end{array}$ & $\begin{array}{l}\text { Ghost Wipe }^{\mathrm{TM}} \\
\text { (\% recovery) }\end{array}$ & $\begin{array}{c}\text { High Purity }^{\mathrm{TM}} \mathrm{BeO} \\
\text { spiked MCE filter } \\
\text { (\% recovery) }\end{array}$ \\
\hline \multirow{4}{*}{$\begin{array}{c}\text { Blank: } 0 \mu \mathrm{g} \\
\text { Be }\end{array}$} & $0.06 \mu \mathrm{g}$ & $<0.005 \mu \mathrm{g}$ & $<0.005 \mu \mathrm{g}$ \\
\hline & $0.03 \mu \mathrm{g}$ & $<0.005 \mu \mathrm{g}$ & $<0.005 \mu \mathrm{g}$ \\
\hline & $0.04 \mu \mathrm{g}$ & & $<0.005 \mu \mathrm{g}$ \\
\hline & & & $<0.005 \mu \mathrm{g}$ \\
\hline \multirow{5}{*}{$\begin{array}{l}\text { Spiked with } \\
\text { Be acetate, } \\
0.04 \mu g \text { Be }\end{array}$} & $0.061 \mu \mathrm{g}(153 \%)$ & $0.04 \mu \mathrm{g}(100 \%)$ & \\
\hline & $0.057 \mu \mathrm{g}(139 \%)$ & $0.041 \mu \mathrm{g}(103 \%)$ & \\
\hline & $0.064 \mu \mathrm{g}(160 \%)$ & $0.04 \mu \mathrm{g}(100 \%)$ & \\
\hline & $0.049 \mu \mathrm{g}(120 \%)$ & $0.037 \mu \mathrm{g}(93 \%)$ & \\
\hline & $0.063 \mu \mathrm{g}(154 \%)$ & $0.038 \mu \mathrm{g}(93 \%)$ & \\
\hline \multirow{5}{*}{$\begin{array}{c}\text { Spiked with } \\
\text { Be Oxide, } \\
\text { 0.004 } \mu \mathrm{g} \mathrm{Be}\end{array}$} & & & $0.0038 \mu \mathrm{g}(93 \%)$ \\
\hline & & & $0.0038 \mu \mathrm{g}(93 \%)$ \\
\hline & & & $0.0038 \mu \mathrm{g}(93 \%)$ \\
\hline & & & $0.004 \mu \mathrm{g}(100 \%)$ \\
\hline & & & $0.004 \mu \mathrm{g}(100 \%)$ \\
\hline
\end{tabular}

* Filters were spiked with a concentration of beryllium that is less than the established method reporting limit. The quantification limit for MCE wipes was found to be $0.005 \mu \mathrm{g}$.

To establish the reproducibility of the low background fluorescence of the wet Ghost Wipes $^{\mathrm{TM}}$, two different lots were tested as shown in Table 3 which shows no significant variation between the two lots. 
Table 3: Ghost Wipe ${ }^{\mathrm{TM}}$ Lot Comparison for Background Fluorescence

\begin{tabular}{|c|c|c|c|c|}
\hline Sample & $\begin{array}{c}\text { Ave, } \\
\text { ppb }\end{array}$ & $\begin{array}{c}\text { Std Dev, } \\
\text { ppb }\end{array}$ & Ave, $\boldsymbol{\mu g}$ & $\begin{array}{c}\text { Std Dev, } \\
\boldsymbol{\mu g}\end{array}$ \\
\hline Lot\# Aug 4 & 0.02000 & 0.00000 & 0.00800 & 0.00000 \\
\hline Lot \# Oct 29 & 0.02037 & 0.00111 & 0.00815 & 0.00044 \\
\hline Average & 0.02022 & 0.00067 & 0.00809 & 0.00027 \\
\hline Aug 4 data based on 6 samples, and three aliquots were measured from each sample. \\
\hline Oct 29 data based on 9 samples; three aliquots were measured from each sample. \\
\hline
\end{tabular}

The reporting limit for MCE filters spiked with $0.08 \mu \mathrm{g}$ of $\mathrm{Be}(\mathrm{as} \mathrm{BeO})$ was determined by optical fluorescence as shown in Table 4. Limit of detection (LOD) was calculated using standard statistical "t" test at 99\% confidence limits. The lower limit of quantification (LOQ) was obtained by multiplying the LOD by 5 and then averaging the three values. The LOQ for beryllium on MCE filters was, on average, $0.003 \mu \mathrm{g}$.

Table 4: Method Reporting Limit for MCE Filters

\begin{tabular}{|c|c|c|c|}
\hline Standard Conc. Used $=$ & $0.08 \mathrm{ppb}$ & $0.08 \mathrm{ppb}$ & $0.08 \mathrm{ppb}$ \\
\hline Replicate Number ${ }^{(1,2 \ldots 10)}$ & $\begin{array}{l}\text { Measured } \\
\text { Values } \\
\text { (ppb) }\end{array}$ & $\begin{array}{l}\text { Measured } \\
\text { Values } \\
\text { (ppb) }\end{array}$ & $\begin{array}{l}\text { Measured } \\
\text { Values } \\
\text { (ppb) }\end{array}$ \\
\hline 1 & 0.070 & 0.070 & 0.050 \\
\hline 2 & 0.070 & 0.070 & 0.070 \\
\hline 3 & 0.080 & 0.080 & 0.070 \\
\hline 4 & 0.080 & 0.070 & 0.080 \\
\hline 5 & 0.080 & 0.070 & 0.040 \\
\hline 6 & 0.090 & 0.070 & 0.050 \\
\hline 7 & 0.080 & 0 & 0.060 \\
\hline 8 & 0.070 & 0 & 0.070 \\
\hline 9 & 0.090 & 0.070 & 0.080 \\
\hline 10 & 0.080 & 0.080 & 0.060 \\
\hline${ }^{(1,2)}$ Number Measurements $(\mathrm{n})=$ & 10 & 10 & 10 \\
\hline Standard Deviation $(\mathrm{S})=$ & 0.007 & 0.005 & 0.013 \\
\hline (4) Standard Conc. / S = & 11 & 15 & 6 \\
\hline${ }^{(5)}$ Student's t $(\sigma=0.99, n-1)=$ & 2.8214 & 2.8214 & 2.8214 \\
\hline (6) Lower Limit of Detection (LOD) $=$ & 0.02082 & 0.01457 & 0.03774 \\
\hline $\begin{array}{r}{ }^{(6)} \text { Lower Limit of Quantitation (LOQ) } \\
=\end{array}$ & 0.10409 & 0.07285 & 0.18868 \\
\hline Lower Limit of Quantitation $(\mu \mathrm{g})=$ & $\begin{array}{r}\mathbf{0 . 0 0 2} \\
\mu \mathrm{g} / \mathrm{filter}\end{array}$ & $\begin{array}{r}\mathbf{0 . 0 0 2} \\
\mu \mathrm{g} / \text { filter }\end{array}$ & $\begin{array}{r}\mathbf{0 . 0 0 4} \\
\mu \mathrm{g} / \text { filter }\end{array}$ \\
\hline
\end{tabular}


The method reporting limit for Ghost Wipes ${ }^{\mathrm{TM}}$ is shown in Table 5 based on three wipe samples spiked with $0.10 \mu \mathrm{g}$ of beryllium, as beryllium acetate. ]

Table 5: Method Reporting Limit for Ghost Wipes ${ }^{\mathrm{TM}}$

\begin{tabular}{|c|c|c|c|}
\hline Standard Conc. Used = & $0.10 \mathrm{ppb}$ & $0.10 \mathrm{ppb}$ & $0.10 \mathrm{ppb}$ \\
\hline Replicate Number $(1,2 \ldots 10)$ & $\begin{array}{c}\text { Measured } \\
\text { Values }\end{array}$ & $\begin{array}{l}\text { Measured } \\
\text { Values }\end{array}$ & $\begin{array}{l}\text { Measured } \\
\text { Values }\end{array}$ \\
\hline 1 & 0.090 & 0.090 & 0.100 \\
\hline 2 & 0.100 & 0.090 & 0.100 \\
\hline 3 & 0.100 & 0.090 & 0.100 \\
\hline 4 & 0.100 & 0.100 & 0.080 \\
\hline 5 & 0.100 & 0.100 & 0.100 \\
\hline 6 & 0.090 & 0.130 & 0.100 \\
\hline 7 & 0.110 & 0.090 & 0.100 \\
\hline 8 & 0.100 & 0.100 & 0.090 \\
\hline 9 & 0.100 & & 0.090 \\
\hline 10 & 0.110 & & 0.100 \\
\hline$(1,2)$ Number Measurements $(\mathrm{n})=$ & 10 & 8 & 10 \\
\hline Standard Deviation $(\mathrm{S})=$ & 0.007 & 0.014 & 0.007 \\
\hline${ }^{(4)}$ Standard Conc. $/ \mathrm{S}=$ & 15 & 7 & 14 \\
\hline${ }^{(5)}$ Student's t $(\sigma=0.99, \mathrm{n}-1)=$ & 2.8214 & 2.9979 & 2.8214 \\
\hline${ }^{(6)}$ Lower Limit of Detection $(\mathrm{LOD})=$ & 0.01881 & 0.04066 & 0.01973 \\
\hline${ }^{(6)}$ Lower Limit of Quantitation (LOQ) = & 0.09405 & 0.20329 & 0.09864 \\
\hline Lower Limit of Quantitation $(\mu \mathrm{g})=$ & $\begin{array}{r}\mathbf{0 . 0 0 9} \\
\mu \mathrm{g} / \text { wipe }\end{array}$ & $\begin{array}{r}\mathbf{0 . 0 2 0} \\
\mu \mathrm{g} / \text { wipe }\end{array}$ & $\begin{array}{r}\mathbf{0 . 0 1 0} \\
\mu \mathrm{g} / \text { wipe }\end{array}$ \\
\hline
\end{tabular}

Based on the three sets of experiments the average LOQ for the Ghost Wipes ${ }^{\mathrm{TM}}$ was $0.013 \mu \mathrm{g}$. In many beryllium-contaminated environments, the beryllium present is in the oxide form. To determine the recoveries of $\mathrm{BeO}$ in the presence of Ghost Wipes, $\mathrm{BeO}$ spiked MCE filters were inserted in the dissolution tubes along with blank Ghost Wipes. $20 \mathrm{ml}$ of $\mathrm{ABF}$ was added for dissolution at $90^{\circ} \mathrm{C}$ for one hour. Although NIOSH methods 7704 and 9110 recommend a 30-minute heating step, other studies [15] have shown that heating for one hour can give a better beryllium recovery (up to $20 \%$ improvement for $\mathrm{BeO}$ containing samples). The resulting solution was then analyzed as previously described. The recovery data for beryllium under such conditions are shown in Table 6 . 
Table 6: Recovery of Ghost Wipes ${ }^{\mathrm{TM}}$ Combined with HPTM MCE BeO Standards

\begin{tabular}{|c|c|c|c|c|}
\hline Concentration & $\begin{array}{c}\text { Expected } \\
\text { Value, } \boldsymbol{\mu g}\end{array}$ & Result, ppb & Result, $\boldsymbol{\mu g}$ & \% Recovery \\
\hline $\mathrm{BeO} \mathrm{0.01*}$ & 0.01 & 0.14 & 0.014 & 140.0 \\
\hline $\mathrm{BeO} \mathrm{0.01*}$ & 0.01 & 0.11 & 0.011 & 110.0 \\
\hline $\mathrm{BeO} 0.2$ & 0.2 & 2.01 & 0.201 & 100.5 \\
\hline $\mathrm{BeO} 0.2$ & 0.2 & 1.92 & 0.192 & 96.0 \\
\hline $\mathrm{BeO} 0.5$ & 0.5 & 4.88 & 0.488 & 97.6 \\
\hline $\mathrm{BeO} 0.5$ & 0.5 & 4.51 & 0.451 & 90.2 \\
\hline $\mathrm{BeO} 1.0$ & 1 & 9.19 & 0.919 & 91.9 \\
\hline $\mathrm{BeO} 1.0$ & 1 & 8.97 & 0.897 & 89.7 \\
\hline
\end{tabular}

*Concentration below established Method Reporting Limit.

At the low $\mathrm{BeO}$ concentration of $0.01 \mu \mathrm{g}$ the background from both the Ghost Wipe $^{\mathrm{TM}}$ and MCE filter are adding to the fluorescence signal resulting in recovery values higher than $100 \%$. As the value of the $\mathrm{BeO}$ increases above the established method reporting limit of $0.02 \mu \mathrm{g}$, the effect of the background signal is diminished and the recovery values are in the low to high $90 \%$ range.

Since many of the wipe samples will be taken in areas where other metals are present, and even in some cases in the presence of radioactive materials interference can be an issue. The metals Fe and Ti can cause yellow-colored solutions, which can interfere with Be analysis results by producing a negative bias, either via excessive absorption of the excitation beam or through absorption of the emission signal by the solution. These interfering metals were chosen as additional spike materials for the Ghost Wipes, in combination with the $\mathrm{BeO}$-spiked MCE filters. Also chosen was a low dosage of $\mathrm{Pu}$. The recovery data for the interference testing are shown in Table 7. 
Table 7: Interference Testing: Fe/Ti/Pu in Ghost Wipes ${ }^{\mathrm{TM}}$

\begin{tabular}{|c|c|c|c|c|c|}
\hline Interference & $\begin{array}{c}\text { Conc } \\
\text { Interference }\end{array}$ & $\begin{array}{c}\text { Conc Be } \\
\text { (ppb) }\end{array}$ & $\begin{array}{c}\text { Be Result } \\
\text { (ppb) }\end{array}$ & Recovery & $\begin{array}{c}\text { Mean } \\
\text { (standard Deviation) }\end{array}$ \\
\hline $\mathrm{Fe}$ & $10 \mathrm{mg}$ & 0.2 & 0.2 & $\mathbf{1 0 0}$ & - \\
\hline & $10 \mathrm{mg}$ & 0.2 & 0.16 & $\mathbf{7 5}$ & - \\
\hline & $10 \mathrm{mg}$ & 2 & 1.74 & $\mathbf{8 7}$ & - \\
\hline & $10 \mathrm{mg}$ & 2 & 1.76 & $\mathbf{8 8}$ & - \\
\hline & $10 \mathrm{mg}$ & 0.2 & 0.21 & $\mathbf{1 0 5}$ & - \\
\hline & $10 \mathrm{mg}$ & 0.2 & 0.2 & $\mathbf{1 0 0}$ & - \\
\hline & $10 \mathrm{mg}$ & 0.2 & 0.27 & $\mathbf{1 3 5}$ & - \\
\hline & $10 \mathrm{mg}$ & 0.2 & 0.23 & $\mathbf{1 1 5}$ & - \\
\hline & $10 \mathrm{mg}$ & 2 & 1.84 & $\mathbf{9 2}$ & - \\
\hline & $10 \mathrm{mg}$ & 2 & 1.8 & $\mathbf{9 0}$ & $\mathbf{9 9}(\mathbf{1 7})$ \\
\hline & $2 \mathrm{mg}$ & 0.2 & 0.21 & $\mathbf{1 0 5}$ & - \\
\hline $\mathrm{Ti}$ & $2 \mathrm{mg}$ & 0.2 & 0.22 & $\mathbf{1 1 0}$ & - \\
\hline & $2 \mathrm{mg}$ & 2 & 1.72 & $\mathbf{8 6}$ & - \\
\hline & $2 \mathrm{mg}$ & 2 & 1.69 & $\mathbf{8 5}$ & $\mathbf{9 7}(\mathbf{1 3 )})$ \\
\hline & $\sim 5 \mathrm{E} 6 \mathrm{dpm} * *$ & 0.2 & 0.21 & $\mathbf{1 0 5}$ & - \\
\hline $\mathrm{Pu}$ & $\sim 5 \mathrm{E} 6 \mathrm{dpm} * *$ & 0.2 & 0.2 & $\mathbf{1 0 0}$ & - \\
\hline & $\sim 5 \mathrm{E} 6 \mathrm{dpm} * *$ & 2 & 1.85 & $\mathbf{9 3}$ & $\mathbf{9 9}(\mathbf{6})$ \\
\hline $\mathrm{HP}-\mathrm{CRMD}$ & $\mathrm{n} / \mathrm{a}$ & 0.1 & 0.104 & $\mathbf{1 0 4}$ & - \\
\hline HP-CRME & $\mathrm{n} / \mathrm{a}$ & 0.2 & 0.201 & $\mathbf{1 0 1}$ & - \\
\hline Blank & $\mathrm{n} / \mathrm{a}$ & 0 & 0.04 & $\mathbf{n} / \mathbf{a}$ & - \\
\hline Blank & $\mathrm{n} / \mathrm{a}$ & 0.01 & 0.04 & $\mathbf{n} / \mathbf{a}$ & - \\
\hline Blank & $\mathrm{n} / \mathrm{a}$ & 0.01 & 0.02 & $\mathbf{n} / \mathbf{a}$ & - \\
\hline
\end{tabular}

*CRM D and CRME are spiked filters prepared by High Purity Standards, with beryllium acetate in known concentrations indicated.

** approximately $5 \times 10^{6}$ disintegrations per minute of alpha activity, contributed to plutonium.

The Ti and Pu additives show no interference effects and give recovery values in line with those shown on Table 6 where the additive materials were not present. The 10 mg Fe additive appears to affect the recovery in some instances. This stresses the importance of measuring spiked samples routinely with field samples (in a similar way, ICP-AES requires interference correction for high iron levels). Even in the example shown, the average recovery was $98.7 \%$ with a standard deviation of $16.9 \%$. 


\section{Conclusions}

Based on the information provided in this article, it is concluded that some commercially available wet wipes would be suitable for beryllium wipe measurement by fluorescence. Because there is no current standard that commercially available wet wipes must adhere to for beryllium measurement, wipes used would require lot testing to provide documentation of suitability.

\section{Acknowledgements}

The authors gratefully acknowledge Shirley Riley, Erika Lee, and Chad Durden, for generation of the data used in the tables provided.

\section{References}

1. Cronin, JP., Agrawal, A., Adams, L., Tonazzi, JCL., Brisson, MJ., White, KT., Marlow, D., and Ashley, K.: Interlaboratory evaluation of an extraction and fluorescence method for the determination of trace beryllium in soils. Journal of Environmental Monitoring, Vol. 10, pp. 955 - 960 (2008).

2. Ashley, K., Agrawal, A., Cronin, J., Tonazzi, J., McCleskey, TM., Burrell, AK., and Ehler, DS.: Ultra-trace determination of beryllium in occupational hygiene samples by ammonium bifluoride extraction and fluorescence detection using hydroxybenzoquinoline sulfonate. Analytica Chimica Acta, Vol. 584, pp. 281-286 (2007).

3. Agrawal, A., Cronin, J., Tonazzi, J., McCleskey, TM., Ehler, DS., Minogue, EM., Whitney, G., Brink, C., Burrell, AK., Warner, B., Goldcamp, MJ., Schlect, PC., Sonthalia, P., and Ashley, K.: Validation of a Portable Fluorescence Method for the Measurement of Trace Beryllium in the Workplace Air and Wipe Samples. Journal of Environmental Monitoring, Vol. 8, pp. 619-624 (2006).

4. Ashley, K., McCleskey, TM., Brisson, M., Goodyear, G., Cronin J., and Agrawal, A.: Interlaboratory Evaluation of a Portable Fluorescence Method for the Measurement of Trace Beryllium in the Workplace. Journal of ASTM International, Vol. 2(9), paper ID JAI13156 (2005).

5. Ashley K., Oatts TJ. [2009]: Sample dissolution reagents for beryllium Applications in occupational and environmental hygiene (Chap. 4). In Beryllium Environmental Analysis and Monitoring; Brisson MJ, Ekechukwu A, Eds. Royal Society of Chemistry (RSC): Cambridge, UK; pp. 89-101.

6. Maxwell III, SL., Bernard, MA., Nelson, MR., Youmans, LD., New method for removal of spectral interferences for beryllium assay using inductively coupled plasma atomic emission spectrometry, Talanta Vol 76 (2008) pp 432-440

7. "Twice the samples, half the time," The Y12 Report, Vol.7(1) p.7, Spring (2010); http://www.y12.doe.gov/news/report/toc.php?vn=7_1\&xml=p07 
8. ASTM D7202, Standard Test Method for Determination of Beryllium in the Workplace Using Field-Based Extraction and Fluorescence Detection. ASTM International, West Conshohocken, PA, USA (2005).

9. ASTM D7458, - 08, Standard Test Method for Determination of Beryllium in Soil, Rock, Sediment, and Fly Ash Using Ammonium Bifluoride Extraction and Fluorescence Detection. ASTM International, West Conshohocken, PA, USA (2008).

10. US National Institute for Occupational Safety and Health (NIOSH), NIOSH Manual of Analytical Methods, $5^{\text {th }}$ ed., Method Nos. 7704: Beryllium in Air by Field-Portable Fluorometry, and Method Nos. 9110: Beryllium in Surface Wipes by Field-Portable Fluorometry. NIOSH, Cincinnati, OH (2007).

11. US National Institute for Occupational Safety and Health (NIOSH), NIOSH Manual of Analytical Methods, $4^{\text {th }}$ ed., Method Nos. 7102 and 7300, NIOSH, Cincinnati, OH (1994).

12. US Environmental Protection Agency (EPA), Trace Elements in Water \& Wastes ICP-MS, Method No. 200.8, EPA, Washington, DC (1994).

13. Minogue, EM., Burrell, AK., McCleskey, TM., Taylor, TP.: Development of a New Fluorescence Method for the Detection of Beryllium on Surfaces, Journal of ASTM International, Vol. 2(10), (2006); Paper ID JAI13168.

14. Dufay, SK., and Archuleta, M., Comparison of collection efficiencies of sampling methods for removable beryllium surface contamination, Journal of Environmental Monitoring, Vol 8, pp. 630-633 (2006)

15. Goldcamp, MJ., Goldcamp, DM., Ashley, K., Fernback, JE., Agrawal, A., Millson, M., Marlow, D., and Harrison, K., Extraction of Beryllium from Refractory Beryllium Oxide with Dilute Ammonium Bifluoride and Determination by Fluorescence - A Multiparameter Performance Evaluation. Journal of Occupational and Environmental Hygiene, Vol. 6, pp. 735-744 (2009). 